\title{
HUBUNGAN ANTARA BEBAN KERJA DENGAN STRES KERJA PADA PERAWAT PELAKSANA RUANG RAWAT INAP
}

\author{
Evi Sunarti', Supriyati², Junaidi ${ }^{3}$ \\ 1,2,3 Program Studi Psikologi, Fakultas Kedokteran Universitas Malahayati. Email: viroyoga@yahoo.com
}

ABSTRACT: RELATIONSHIP BETWEEN WORKLOAD AND WORK STRESS IN INPATIENT NURSES

The industrialization era demands that all components in the world of work run as optimally as possible. This result in hight demand on workers so that it ultimately lead to work stress. This study aimed to determine the relationship between workload and work stress on nurses in the inpatient room at Pertamina Bintang Amin Hospital Lampung. This research is an analytical research with a cross-sectional approach, Data collection techniques in this study using work stress scale and workload scale. The sample of this study were 33 nurses administered in the Inpatient Room of Pertamina Bintang Amin Hospital Lampung. Data analysis in this study using product moment correlation analysis techniques. Based on the results of data analysis, there is a positive significant relationship between workload and work stress in the implementing nurse in the inpatient room.

\section{Keywords: Workload, Work Stress, Nurse}

Era Industrialisasi menuntut seluruh komponen dalam dunia kerja dapat bekerja seoptimal mungkin. Hal ini menghasilkan tuntutan yang besar pada pekerja sehingga pada akhirnya dapat menimbulkan stres kerja. Penelitian ini bertujuan untuk mengetahui hubungan antara beban kerja dengan stress kerja pada perawat. Penelitian ini merupakan penelitian analitik dengan pendekatan cross-sectional. Sampel dalam penelitian ini adalah 33 perawat pelaksana ruang rawat Rumah Sakit Pertamina Bintang Amin Lampung. Teknik pengumpulan data dalam penelitian ini menggunakan skala stres kerja dan skala beban kerja. Populasi dalam penelitian ini adalah Perawat Pelaksana di Ruang Instalasi Rawat Inap Rumah Sakit Pertamina Bintang Amin Bandar Lampung. Analisis data dalam penelitian ini menggunakan teknik analisis korelasi product moment. Berdasarkan hasil analisis data diketahui terdapat hubungan positif yang signifikasn antara beban kerja dengan stres kerja pada perawat pelaksana di ruang rawat inap..

\section{Kata Kunci : Beban Kerja, Stres Kerja, Perawat}

\section{PENDAHULUAN}

Tuntutan yang besar pada pekerja pada akhirnya dapat menimbulkan stres kerja. Stres kerja merupakan hal yang sering dialami oleh para pekerja. Hal tersebut juga terjadi pada profesi perawat yang memiliki tugas dan tanggung jawab yang cukup mempengaruhi tingkat Stres pada diri mereka. Stres kerja adalah kondisi yang muncul dari interaksi antara manusia dan pekerjaan serta dikarakterisasikan oleh perubahan manusia yang memaksa mereka untuk menyimpang dari fungsi normal mereka (Luthans, 2006).

Stres yang berhubungan dengan pekerjaan memiliki dua sumber utama yaitu, tuntutan emosional dari lingkungan kerja dan kemampuan karyawan untuk mengontrol emosi. Karyawan yang memiliki tuntutan emosional yang tinggi pada pekerjaannya dalam mengontrol emosi akan mengalami stres yang tinggi. Hal ini tidak hanya dialami oleh profesi perawat. Dalam teori psikologi didefinisikan bahwa stres kerja merupakan kondisi ketegangan yang menciptakan 


\section{HUBUNGAN BEBAN KERJA DENGAN STRES KERJA PADA PERAWAT PELAKSANA RUANG RAWAT INAP}

ketidakseimbangan fisik dan psikis, yang mempengaruhi emosi, proses berpikir, dan kondisi individu. Stres kerja banyak terjadi pada individu dengan latar belakang di bidang pelayanan, yaitu orang-orang yang bekerja pada bidang pelayanan kemanusiaan dan berkaitan erat dengan masyarakat. Kondisi di atas sejalan dengan situasi yang terjadi saat ini dimana dunia sedang mengalami pandemi corona yang disebabkan oleh virus COVID-19, hampir seluruh belahan negara didunia mengalami pandemi COVID-19, dan sudah banyak yang terpapar virus ini termasuk di Indonesia khususnya diprovinsi Lampung. Berdasarkan data yang dirilis dari dinas kesehatan Provinsi Lampung pertanggal 10 April 2020, upadate Coranavirus Disease Provinsi Lampung kasus terkonfirmasi positif sebanyak 21 orang dengan rincian : 9 pasien masih dirawat, 5 meninggal dan 7 pasien dinyatakan sembuh. Sedangkan Orang dalam Pemantauan (ODP) sebanyak 2259 orang dan Pasien Dalam Pengawasan (PDP) sebanyak 49 orang, sehingga hal tersebut meningkatkan stres kerja pada perawat (Kemenkes RI, 2020).

Stres kerja pada perawat merupakan salah satu permasalahan dalam manajemen sumber daya manusia di rumah sakit. Stres merupakan suatu respons adaptif terhadap suatu situasi yang dirasakan menantang atau mengancam kesehatan seseorang (Sopiah, 2008). Dalam menjalankan profesinya perawat rawan terhadap stres. Menurut hasil survei dari
PPNI (Persatuan Perawat Nasional Indonesia) tahun 2006, sepenulisr $50.9 \%$ perawat yang bekerja di empat provinsi di Indonesia mengalami stres kerja, sering pusing, lelah, tidak bisa beristirahat karena beban kerja terlalu tinggi dan menyita waktu (Muchransyah \& Rachmawati, 2016).

Berdasarkan penelitian terdahulu yaitu hasil penelitian Martini (2012) menunjukkan bahwa dari 69 perawat (86\%) yang bekerja diruang rawat inap RSPG Cisarua Bogor berada pada tingkat stres kerja sedang (Martini, 2012). Penelitian lain yang sejalan yaitu penelitian Prima (2012) yang berjudul hubungan antara beban kerja dengan stres kerja pada perawat ruang rawat inap di Rumah Sakit Daerah Dr. Soebandi Jember menunjukkan beban kerja $40 \%$ responden ada pada kategori ringan dan $50 \%$ responden pada kategori sedang, sedangkan $10 \%$ responden ada pada kategori beban kerja berat. Untuk variabel stress kerja $41,7 \%$ responden ada pada kategori stres kerja sedang, dan sisanya pada kategori ringan dengan korelasi yang cukup berarti yaitu $r=$ $.586, p<.01$ (Prima, 2012).

Lingkungan rumah sakit sebagaimana lingkungan organisasi lainnya menuntut adanya penyesuaian diri dari individu yang menempatinya. Oleh karena itu dengan beban kerja yang ada dapat menyebabkan stres kerja pada perawat di rumah sakit. Berkaitan dengan alasan tersebut maka peneliti perlu mengkaji tentang hubungan beban kerja dengan stres

Evi Sunarti, Program Studi Psikologi Fakultas Kedokteran Universitas Malahayati. Email: viroyoga@yahoo.com

Supriyati, Program Studi Psikologi Fakultas Kedokteran Universitas Malahayati.

Junaidi, Program Studi Psikologi Fakultas Kedokteran Universitas Malahayati. 


\section{HUBUNGAN BEBAN KERJA DENGAN STRES KERJA PADA PERAWAT PELAKSANA RUANG RAWAT INAP}

kerja pada perawat terutama pada Rawat Inap Rumah Sakit Pertamina Bintang Amin Bandar Lampung.

Berdasarkan uraian di atas, maka peneliti tertarik untuk mengetahui apakah ada hubungan antara beban kerja dengan stres kerja perawat pelaksana di Ruang Instalasi Rawat Inap Rumah Sakit Pertamina Bintang Amin Bandar Lampung?

\section{METODE}

Penelitian ini menggunakan metode kuantitatif. Penelitian ini dilakukan di Rumah Sakit Pertamina Bintang Amin Lampung. Populasi penelitian ini adalah perawat di ruang rawat inap di Rumah Sakit Pertamina Bintang Amin yang terdiri dari laki-laki dan perempuan dan memiliki latar pendidikan Diploma 3 dan Strata 1. Teknik sampling yang digunakan adalah total populasi, artinya besar sampel yang digunakan dalam penelitian ini adalah seluruh perawat pelaksana di ruang Instalasi Rawat Inap Rumah Sakit Pertamina Bintang Amin Bandar Lampung sebanyak 33 orang. Pelaksanaan pengambilan data dilakukan mulai tanggal 19-24 Agustus 2020.

Metode pengumpulan data menggunakan Skala Stress Kerja dan Skala Beban Kerja model skala likert. Skala Stres Kerja berdasarkan Teori Robbins (2013) dengan aspeknya adalah gejala fisiologis, gejala psikologis dan gejala prilaku. Sedangkan Skala beban kerja disusun menggunakan skala beban kerja yaitu : aspek beban kerja fisik, beban kerja mental, dan beban kerja waktu. Suatu alat ukur dapat dikatakan mempunyai validitas yang tinggi apabila alat tersebut menjalankan fungsi ukurnya atau memberikan hasil ukur yang sesuai dengan maksud dilakukan pengukuran tersebut (Manuaba, 2000). Validitas isi adalah sejauh mana isi skala tersebut mencakup data yang komprehensifdan relevan dengan tujuan penelitian (Azwar, 2015).

Uji validitas dalam penelitian ini menggunakan korelasi product moment dengan bantuan program SPSS 21.0. Uji reliabilitas yang digunakan dalam penelitian ini reliabilitas konsistensi internal dengan rumus Alpha Cronbach. Perhitungan Alpha Cronbach dilakukan dengan menghitung rata-rata interkorelasi diantara butir-butir pernyataan dalam kuisioner. Hasil uji validitas dan reliabilitas alat ukur skala beban kerja diperoleh $r_{i t}=.510-.636$ dan koefisien reliabilitas alpha cronbach sebesar .951. Jumlah subjek penelitian adalah 33 orang. Peneliti memberikan skala kepada responden melalui Google Form dikarenakan masa Pandemi Covid-19. Data didapatkan dari hasil pengisian kuesioner pada perawat di ruang rawat inap di Rumah Sakit Pertamina Bintang Amin. Analisis data dalam penelitian ini adalah dengan menggunakan teknik analisis korelasi product moment.

Evi Sunarti, Program Studi Psikologi Fakultas Kedokteran Universitas Malahayati. Email: viroyoga@yahoo.com

Supriyati, Program Studi Psikologi Fakultas Kedokteran Universitas Malahayati. Junaidi, Program Studi Psikologi Fakultas Kedokteran Universitas Malahayati. 


\section{HUBUNGAN BEBAN KERJA DENGAN STRES KERJA PADA PERAWAT PELAKSANA RUANG} RAWAT INAP

\section{HASIL}

Berdasarkan hasil analisis univariat diperoleh hasil distribusi responden sebagai berikut :

Tabel 1

Distribusi Karakteristik Responden

\begin{tabular}{|c|c|c|}
\hline \multicolumn{3}{|c|}{ Karakteristik Responden berdasarkan Usia } \\
\hline Usia & Frekuensi & $\%$ \\
\hline $23-26$ tahun & 16 & 48 \\
\hline $27-31$ tahun & 17 & 52 \\
\hline Jumlah & 33 & 100 \\
\hline \multicolumn{3}{|c|}{ Karakteristik Responden Berdasarkan Pendidikan } \\
\hline Pendidikan & Frekuensi & $\%$ \\
\hline D3 & 21 & 64 \\
\hline S1 & 12 & 36 \\
\hline Jumlah & 33 & 100 \\
\hline \multicolumn{3}{|c|}{ Karakteristik Responden Berdasarkan Jenis Kelamin } \\
\hline Jenis Kelamin & Frekuensi & $\%$ \\
\hline Laki-laki & 10 & 30 \\
\hline Perempuan & 23 & 70 \\
\hline Jumlah & 33 & 100 \\
\hline
\end{tabular}

Berdasarkan tabel 1 diatas tentang distribusi karakteristik responden didapatkan hasil rata-rata responden berusia antara 27-31 tahun sebanyak 17 orang (52\%) dengan latar belakang pendidikan terbanyak yaitu Diploma (D3) sebanyak 21 orang (64\%), serta rata-rata responden berjenis kelamin perempuan sebanyak 23 orang $(70 \%)$.

Tabel 2

Deskripsi Data Penelitian: Beban Kerja dan Stres Kerja

\begin{tabular}{ccccccccc}
\hline \multirow{2}{*}{ Variabel } & \multirow{2}{*}{ A } & \multicolumn{4}{c}{ Skor Empirik } & \multicolumn{3}{c}{$\begin{array}{c}\text { Skor } \\
\text { Hipotetik }\end{array}$} \\
\cline { 4 - 9 } & & & Min & Maks & Means & SD & Min & Maks \\
\hline Beban Kerja & 33 & 36 & 48 & 72 & 60 & 4 & 36 & 144 \\
Stres Kerja & 33 & 30 & 48 & 76 & 62 & 5 & 30 & 120 \\
\hline
\end{tabular}

Tabel 3

Kategorisasi Variabel Beban Kerja dan Stres Kerja

\begin{tabular}{lllll}
\hline & \multicolumn{2}{c}{ Beban Kerja } & & Stres Kerja \\
\cline { 2 - 5 } & $\mathrm{F}$ & $\%$ & $\mathrm{~F}$ & $\%$ \\
\hline Rendah & 6 & 15 & 9 & 27 \\
\hline Sedang & 18 & 55 & 22 & 67 \\
\hline Tinggi & 10 & 30 & 2 & 6 \\
\hline \multicolumn{2}{r}{ Berdasarkan tabel deskripsi } & data & penelitian beban & kerja dan stress \\
& &
\end{tabular}

Evi Sunarti, Program Studi Psikologi Fakultas Kedokteran Universitas Malahayati. Email: viroyoga@yahoo.com

Supriyati, Program Studi Psikologi Fakultas Kedokteran Universitas Malahayati. Junaidi, Program Studi Psikologi Fakultas Kedokteran Universitas Malahayati. 


\section{HUBUNGAN BEBAN KERJA DENGAN STRES KERJA PADA PERAWAT PELAKSANA RUANG RAWAT INAP}

kategorisasi masing-masing variabel seperti pada tabel 3. Berdasarkan data pada tabel 3 diketahui bahwa sebagian besar responden memiliki beban kerja sedang $(55 \%)$ dan juga stress dalam kategori sedang $(67 \%)$.

Selanjutnya sebelum dilakukan uji hipotesis perlu dilakukan uji asumsi. Uji asumsi yang dimaksud berupa uji normalitas yang termasuk dalam syarat jika akan melakukan uji statistik parametrik. Berdasarkan hasil uji normalitas menunjukkan bahwa skala beban kerja dan stress kerja berdistribusi normal $(p>$.05). Selanjutnya berdasarkan hasil uji linearitas menunjukkan bahwa korelasi antara beban kerja dan stress kerja linear $\left(R=.551, R^{2}=.303, p>.05\right)$.

Tabel 4

Korelasi Beban Kerja dengan Stres Kerja

\begin{tabular}{ll}
\hline & Stres kerja \\
\hline Beban Kerja & $r=.551^{* *}$ \\
\hline$p<.01$ &
\end{tabular}

Berdasarkan hasil uji hipotesis menggunakan analisis product moment dari pearson dapat disimpulkan terdapat hubungan positif signifikan antara beban kerja dengan stress kerja pada perawat rawat inap $(r(33)=.551, p<.01)$

\section{DISKUSI}

\section{Beban Kerja}

Berdasarkan hasil kategorisasi variabel beban kerja Mayoritas responden memiliki beban kerja sedang sebesar $55 \%$. Beban kerja yang dimiliki oleh perawat cukup banyak dan beragam. Kurniadi (2013) mendefinisikan beban kerja perawat adalah seluruh kegiatan atau aktivitas yang dilakukan oleh seorang perawat selama bertugas di suatu unit pelayanan keperawatan. Beban kerja (work load) biasanya diartikan sebagai patient days yang merujuk pada jumlah prosedur, pemeriksaan kunjungan (visite) pada klien. Sedangkan beban kerja psikologis dapat berupa sejauh mana tingkat keahlian dan prestasi kerja yang dimiliki individu dengan individu lainnya (Saribu, 2012).

Hasil sejalan dengan penelitian Martini (2012) menunjukkan bahwa dari 69 perawat $(86 \%)$ yang bekerja diruang rawat inap RSPG Cisarua Bogor mayoritas berada pada tingkat stres kerja sedang (Martini, 2012). Penelitian lain yang sejalan dengan penelitian Prima (2012) tentang hubungan antara beban kerja dengan stres kerja pada perawat ruang rawat inap di Rumah Sakit Daerah Dr. Soebandi Jember menunjukkan mayoritas dengan beban sedang sebesar 50\% responden (Prima, 2012).

Evi Sunarti, Program Studi Psikologi Fakultas Kedokteran Universitas Malahayati. Email: viroyoga@yahoo.com

Supriyati, Program Studi Psikologi Fakultas Kedokteran Universitas Malahayati. Junaidi, Program Studi Psikologi Fakultas Kedokteran Universitas Malahayati. 


\section{HUBUNGAN BEBAN KERJA DENGAN STRES KERJA PADA PERAWAT PELAKSANA RUANG}

RAWAT INAP

\section{Stres Kerja}

Berdasarkan hasil kategorisasi variabel beban kerja Kategorisasi secara empirik pada variabel stres kerja mayoritas memiliki stres kerja sedang sebesar $67 \%$. Pada dasarnya stres kerja yang dialami oleh perawat akan menimbulkan berbagai dampak negatif, yang pada akhirnya perawat tidak dapat menjalankan pekerjaannya secara optimal, efektif dan efisien. Menurut Anoraga (2019), secara sederhana stres merupakan suatu bentuk tanggapan seseorang, baik secara fisik maupun mental, terhadap suatu perubahan di lingkungannya yang dirasakan mengganggu dan mengakibatkan terancam (fight or flaight). Jadi sebenarnya stres adalah sesuatu yang alamiah (Anoraga, 2019). Hasil penelitian sejalan dengan penelitian Prima (2012) mayoritas dengan stress kerja sedang sebanyak 50\% dan berat sebanyak 30\% (Prima, 2012).

\section{Hubungan Beban Kerja dengan Stress Kerja}

Berdasarkan penelitian mengenai beban kerja dengan stres kerja pada perawat di ruang rawat inap di Rumah Sakit Pertamina Bintang Amin didapatkan bahwa dari 33 perawat sebagai responden menunjukkan hasil uji korelasi adanya hubungan yang signifikan antara beban kerja dengan stres kerja pada perawat di ruang rawat inap di Rumah Sakit Pertamina Bintang Amin $(r(33)=.551)$. Hal ini menunjukkan semakin tinggi beban kerja maka semakin tinggi stres kerja. Sebaliknya semakin rendah beban kerja maka semakin rendah stres kerja.

Hasil penelitian ini sesuai dengan yang diasumsikan oleh Anoraga (2019) bahwa beban kerja berlebih secara fisik maupun mental, yaitu harus melakukan terlalu banyak hal, merupakan kemungkinan sumber stres pekerjaan. Unsur yang menimbulkan beban berlebih ialah desakan waktu. Setiap tugas diharapkan dapat diselesaikan secepat mungkin secara tepat dan cermat. Pada saat tertentu, dalam hal tertentu waktu akhir justru dapat meningkatkan motivasi dan menghasilkan prestasi kerja yang tinggi. Namun, bila desakan waktu menyebabkan timbulnya banyak kesalahan akan menyebabkan stress (Anoraga, 2019).

Hasil penelitian ini menguatkan penelitian yang telah dilakukan oleh peneliti sebelumnya antara lain oleh Aini dan Purwaningsih pada tahun 2013 di RSUD kabupaten Semarang, Suratmi dan Wisudawan pada tahun 2015 di ruang Instalasi Gawat Darurat pada RSUD Dr. Soegiri Lamongan dan penelitian yang dilakukan oleh Zailani pada 2011 di ruang perawatan bedah pada RSPAD Gatoto Subroto Jakarta pusat. Dari hasil penelitian-penelitian sebelumnya tersebut diperoleh hasil adanya hubungan yang signifikan antara beban kerja dengan stres kerja pada perawat (Zailani, 2011). Hasil sejalan dengan penelitian Prima (2012) tentang hubungan antara beban kerja dengan stres kerja pada perawat ruang rawat inap di Rumah Sakit Daerah Dr. Soebandi Jember

Evi Sunarti, Program Studi Psikologi Fakultas Kedokteran Universitas Malahayati. Email: viroyoga@yahoo.com

Supriyati, Program Studi Psikologi Fakultas Kedokteran Universitas Malahayati. Junaidi, Program Studi Psikologi Fakultas Kedokteran Universitas Malahayati. 


\section{HUBUNGAN BEBAN KERJA DENGAN STRES KERJA PADA PERAWAT PELAKSANA RUANG RAWAT INAP}

menunjukkan hubungan bermakna antara beban kerja dengan tingkat stress (Prima, 2012).

Penelitian ini masih memiliki keterbatasan, adapun keterbatasan tersebut dikarenakan dalam masa pandemi covid ini maka penelitian yang penulis lakukan dengan cara menyebarkan kuisioner melalui Google Form, maka terdapat beberapa kelemahan atau kesulitan yang penulis alami, antara lain: Tidak bisa bertatap muka langsung dengan responden untuk mendapakan jawaban dalam waktu tertentu, sulit memberikan penjelasan tentang item-item pertanyaan dalam kuisioner yang penulis buat, dan tidak dapat melakukan tanya jawab jika ada yang ingin responden tanyakan kepada penulis.

\section{SIMPULAN DAN SARAN}

Berdasarkan hasil penelitian dapat disimpulkan bahwa terdapat hubungan yang signifikan antara beban kerja dengan stres kerja pada perawat di ruang rawat inap di Rumah Sakit Pertamina Bintang Amin. Pihak rumah sakit dan responden penelitian diharapkan untuk meningkatkan pengelolaan stress kerja melalui layanan konseling, pelatihan dan psikoedukasi managemen stress. Untuk penelitian selanjutnya dapat memperluas cakupan penelitian dengan menambah variabel lain yang berpengaruh pada stres kerja misalnya lingkungan kerja, organisasi dan masalah keluarga serta kuesioner dapat diberikan langsung pada responden.

\section{DAFTAR PUSTAKA}

Aini, F., \& Purwaningsih, P. (2013). Hubungan antara beban kerja dengan stres kerja perawat di Instalasi Gawat Darurat RSUD Kabupaten Semarang. Jurnal Manajemen Keperawatan, 1(1).

Anoraga, P. (2019). Psikologi kerja.

Azwar, S. (2015). Validitas dan Reliabilitas edisi 4. Yogyakarta: Pustaka Pelajar.

Kemekes RI. (2020). Infeksi Emerging Kementrian Kesehatan.

Kurniadi, A. (2013). Manajemen keperawatan dan prospektifnya: Teori, konsep dan aplikasi. Jakarta: Fakultas Kedokteran Universitas Indonesia.

Luthans, F. (2006). Perilaku organisasi.

Manuaba, A. (2000). Ergonomi, kesehatan dan keselamatan kerja. In Proceedings Seminar Nasional Ergonomi.

Martini. 2012. Stres Kerja: Penyebab dan Alternatif Pencegahannya. Julnal Kesehatan. No 31: 71-80.

Muchransyah, M. H. Q., \& Rahmawati, S. (2016). Analisis beban kerja dan kebutuhan pegawai di pusat perpustakaan dan penyebaran teknologi pertanian (PUSTAKA). Jurnal Manajemen dan Organisasi, 7(2), 83-97.

Evi Sunarti, Program Studi Psikologi Fakultas Kedokteran Universitas Malahayati. Email: viroyoga@yahoo.com

Supriyati, Program Studi Psikologi Fakultas Kedokteran Universitas Malahayati. Junaidi, Program Studi Psikologi Fakultas Kedokteran Universitas Malahayati. 
HUBUNGAN BEBAN KERJA DENGAN STRES KERJA PADA PERAWAT PELAKSANA RUANG RAWAT INAP

Prima I. Hubungan Beban Kerja Fisik Dengan Stres Kerja Pada Perawat Ruang Inap Di RSUD Dr. Soebandi Jember. Jember: Fakultas Kesehatan Masyarakat Universitas Jember; 2011

Robbins, S. P., \& Judge, T. A. (2013). Organizational behavior (Vol. 4). New Jersey: Pearson Education.

Saribu, S. D. (2012). Hubungan Beban Kerja dengan Stres Kerja Perawat Pelaksana di Ruang IGD dan ICU RSUD Haji Abdul Manan Simatupang Kisaran. S1 Keperawatan, Skripsi. Universitas
Sumatra Utara. Tersedi dari: http://repository. usu. ac. id. Diakses, 20.

Sopiah, M. (2008). Perilaku Organisasi. Yogyakarta: Andi.

Suratmi, S., \& Wisudawan, A. S. (2015). Hubungan Beban Kerja Dengan Stress Kerja Perawat Pelaksana Di Ruang Igd RSUD Dr. Soegiri Lamongan. Jurnal Keperawatan, 6(2), 137411.

Zailani. (2011). Gambaran Tingkat Stres Pada Pegawai. UI

Evi Sunarti, Program Studi Psikologi Fakultas Kedokteran Universitas Malahayati. Email: viroyoga@yahoo.com

Supriyati, Program Studi Psikologi Fakultas Kedokteran Universitas Malahayati. Junaidi, Program Studi Psikologi Fakultas Kedokteran Universitas Malahayati. 